\title{
PENGARUH EKSTRAKURIKULER BACA TULIS QURAN TERHADAP PRESTASI BELAJAR PESERTA DIDIK PADA MATA PELAJARAN PENDIDIKAN AGAMA ISLAM
}

\author{
Ramdan Hidayat, Try Riduwan Santoso \\ IAILM Suryalaya, \\ hramdan678@gmail.com,tryriduwan165@gmail.com
}

\begin{abstract}
Abstrack
This paper aims to determine the influence of the intensity of students in following extracurricular reading and writing of the Quran at Madrasah Diniyah on achievement in Islamic education subjects at SDN 3 Cibeureum Sukamantri, Ciamis Regency. The method used is descriptive method, because the process of this method is to reveal and analyze and provide an overview of the facts to be studied. Whereas in data collection, researchers used observation, questionnaire, and interview techniques. Hypothesis test results obtained, that there is a positive and significant influence between extracurricular activities of reading and writing the Quran with the learning achievement of students in the subject of Islamic Religious Education. This is evident from the price of the correlation coefficient of 0.88 this figure if interpreted into the interpretation of the correlation coefficient is between 0.81100 .0 with a sufficient correlation level. Then the degree of determination of the relationship is $77 \%$ with a significance level of 0.05 , the list is obtained in the T count list of 4.465 . While the t table is obtained 1.734. So Ha is accepted and Ho is rejected, meaning that there is a significant influence between the intensity of extracurricular activities and the learning achievement of students in the subject of Islamic Religious Education.
\end{abstract}

Keywords: Student Intensity Extracurricular Activities, Learning Achievement

\begin{abstract}
Abstrak
Tulisan ini bertujuan untuk mengetahui bagaimana pengaruh intensitas peserta didik dalam mengikuti ekstrakurikuler Baca Tulis Quran di Madrasah Diniyah terhadap prestasi pada Mata Pelajaran PAI di SDN 3 Cibeureum Sukamantri Kabupaten Ciamis. Metode yang digunakan adalah metode deskriptif, karena proses metode tersebut untuk mengungkapkan dan menganalisis serta memberikan gambaran mengenai fakta-fakta yang akan diteliti. Sedangkan dalam pengumpulan data, peneliti menggunakan teknik observasi, angket, dan wawancara. Hasil uji hipotesis diperoleh, bahwa terdapat pengaruh yang positif dan signifikan antara kegiatan ekstrakurikuler Baca Tulis Quran dengan prestasi belajar peserta didik pada mata pelajaran Pendidikan Agama Islam. Hal ini terbukti dari harga koefisien korelasi sebesar 0,88 angka tersebut jika di interprestasikan ke dalam interprestasi koefisien korelasi berada antara 0,81100,0 dengan tingkat korelasi cukup. Dan derajat determinasi hubungan sebesar 77\% dengan tingkat signifikansi 0,05 diperoleh daftar dalam daftar thitung 4,465. Sedangkan ttabel diperoleh 1,734. Maka Ha diterima dan Ho ditolak, artinya terdapat pengaruh yang signifikan antara intesitas kegiatan ekstrakurikuler dengan prestasi belajar peserta didik pada mata pelajaran Pendidikan Agama Islam.
\end{abstract}

Kata kunci: Intensitas Peserta Didik Kegiatan Ekstrakurikuler, Prestasi Belajar 


\section{A. PENDAHULUAN}

Dalam pendidikan nasional rumusan tujuan pendidikan, baik tujuan kurikuler maupun tujuan intruksional, menggunakan klarifikasi hasil belajar dari Benyami Bloom yang secara garis besar membaginya menjadi tiga ranah, yakni ranah kognitif, ranah afektif dan ranah psikomotorik (Nana Sudjana, 2009). sehingga secara hakikat dipahami bahwa ketiga ranah tersebut menjadi objek penilaian hasil belajar. Hasil belajar terbukti dan terlihat ketika tingkah laku siswa memaparkan perubahan yang terjadi sehingga mengarah dari yang tidak tahu menjadi lebih tahu, tidak bisa menjadi bisa. Hasil belajar tentunya tidak dapat dipisahkan dari proses belajar mengajar yang diatur dalam kurikulum.

Kurikulum dapat dikatakan sebagai alat untuk mencapai tujuan pendidikan. Dalam kurikulum ada program yang bersentuhan langsung dengan proses pendidikan sebagai program ini, yang kemudian dinamakan program kurikuler, dan ada program penunjang yang sifatnya membantu ketercapaian tujuan kurikuler yang kemudian disebut ekstrakurikuler (Asep Herry Hermawan, 2008). Program ekstrakurikuler mencakup kegiatan ekstrakurikuler yang merupakan proses dalam pembelajaran ekstrakurikuler. Hal ini menunjukan terdapat pengaruh antara kegiatan ekstrakurikuler dengan hasil belajar siswa

Hasil penelitian Ahmad Chisni Fahmi dan Jevrie Randy Giovani Nusantara menyimpulkan bahwa kegiatan ekstrakurikuler dapat mengoptimalkan hasil belajar siswa. Hal ini berarti penelitian yang dilakukan menemukan adanya pengaruh yang signifikan antara hasil belajar siswa dengan kegiatan ekstrakurikuler.

Kegiatan Ekstrakurikuler adalah kegiatan yang diselenggarakan di luar jam pelajaran yang tercantum dalam susunan program sesuai dengan keadaan dan kebutuhan sekolah. Berarti, kegiatan ekstrakurikuler ialah kegiatan tambahan karena tidak dilaksanakan di dalam jam pelajaran. Kegiatan ini juga terorganisir karena memiliki program yang akan dilaksanakan sesuai dengan kebutuhan dan keadaan sekolah.

Dari program yang akan dilaksanakan pada kegiatan esktrakurikuler kali ini dimana berupa kegiatan tentang keinginan dan antusias siswa dalam hal Baca Tulis Quran yang diprogramkan di sekolah. Tetapi, diselengarakan di madrasah diniyah dengan adanya kerjasama yang baik.

Baca Tulis Quran merupakan salah satu ekstrakurikuler yang mengajarkan tentang siswa bagaimana membaca, kemudian menulis Alquran. Karena sejak awal diturunkannya Alquran, Allah telah memerintahkan untuk membaca (Iqra') yang terdapat dalam surat $\mathrm{Al}-$ 'Alaq ayat 1 .

سيمبنتششيى:ميسشبتينمستبسي 'Alaq ay

"Bacalah dengan (menyebut) nama Tuhanmu yang Menciptakan" (Tim penerjemah Kemenag RI 2006 : 459 )

Firman Allah dalam surat Al Araf ayat 52 :

يسمنبتسمينبتيسمنبتمسيشتبمسنيت

"Dan Sesungguhnya Kami telah mendatangkan sebuah kitab (Alquran) kepada mereka yang kami telah menjelaskannya atas dasar pengetahuan Kami menjadi petunjuk dan rahmat bagi orang-orang yang beriman”. (Tim penerjemah Kemenag RI 2006 : 119) 
Kemudian dengan diselenggarakannya kegiatan ekstrakurikuler Baca Tulis Quran di madrasah diniyah bertujuan untuk membantu para peserta didik terutama peserta didik yang sekolah di sekolah umum dalam hal mata pelajaran Pendidikan Agama Islam. Karena pada realitanya peserta didik yang bersekolah di sekolah umum waktu yang dimilikinya sangatlah terbatas dan juga sedikit sekali terutama dalam hal mata pelajaran pendidikan agama islam. Sedangkan mengenai Madrasah Diniyah menurut Daradjat (2006 : 104) mengatakan bahwa Madrasah Diniyah adalah lembaga pendidikan dan pengajaran Islam, yang berfungsi terutama untuk memenuhi hasrat orang tua agar anak-anaknya lebih banyak mendapat Pendidikan Agama Islam.

Jadi, diharapkan kegiatan ekstrakurikuler Baca Tulis Quran yang diselenggarakan di Madrasah Diniyah ini mendukung penuh kegiatan kurikuler peserta didik dari awal pembelajaran (planning) hingga pada proses evaluasi (evaluating). Karena keseluruhan dari prinsip manajemen pada hakikatnya selaras dengan tujuan dari kegiatan ekstrakurikuler dilaksanakan.

Tetapi pada kenyataanya berdasarkan studi pendahuluan pada peserta didik, hususnya peserta didik SDN 3 Cibeureum Kabupaten Ciamis didapati keterangan bahwa intensitas peserta didik dalam kegiatan ekstrakurikuler baca tulis Quran di Madrasah Diniyah cukup tinggi bahkan antusias dalam mengikutinya. Penerimaan mereka terhadap intensitas tersebut dapat dibuktikan dengan fakta-fakta antara lain dapat dilihat dari motivasi keinginan peserta didik untuk bisa Baca Tulis Quran yang sangat tinggi, kehadiran mereka yang selalu tepat waktu, adanya aktivitas mereka seperti selalu mendengarkan ketika kegiatan pembelajaran sedang dimulai, selalu memperhatikan setiap pembelajaran sedang berlangsung, kemudian peserta didik selalu bertanya ketika kurang memahami, bisa menjawab di setiap latihan yang diberikan dan juga dengan mereka memiliki buku bimbingan Baca Tulis Quran.

Namun di lain pihak meskipun peserta didik telah mengikuti kegiatan ekstrakurikuler Baca Tulis Quran pada kenyataannya masih terdapat peserta didik yang dikategorikan rendah bahkan bisa disebut juga kurang memuaskan terutama dalam penerapannya dan juga prestasi pada mata pelajaran Pendidikan Agama Islam, dengan fakta masih ada siswa yang sangat lemah dalam pengetahuannya terutama dalam mata pelajaran PAI, masih ada peserta didik yang tidak paham terhadap mata pelajaran PAI, peserta didik masih sulit menerapakan hasil dari kegiatan ektrakurikuler kepada mata pelajaran PAI, Dan masih ada peserta didik yang mendapatkan hasil rendah dari hasil evaluasinya. Berdasarkan fenomena empirik yang terjadi di lapangan, maka penulis merasa tertarik untuk mengetahui data empirik mengenai pengaruh intensitas siswa dalam mengikuti ekstra kurikuler baca tulis Quran terhadap prestasi belajar siswa pada bidang studi PAI.

Berdasarkan latar belakang masalah di atas, penulis dapat merumuskan masalah sebagai berikut: pertama, bagaimana intensitas peserta didik SDN 3 Cibeureum Sukamantri Kabupaten Ciamis dalam mengikuti ekstrakurikuler Baca Tulis Quran di Madrasah Diniyah, kedua, bagaimana prestasi peserta didik SDN 3 Cibeureum Sukamantri Kabupaten Ciamis pada Mata Pelajaran PAI. Ketiga, bagaimana pengaruh intensitas peserta didik dalam mengikuti ekstrakurikuler Baca Tulis Quran di Madrasah 
Diniyah terhadap prestasi pada Mata Pelajaran PAI di SDN 3 Cibeureum Sukamantri Kabupaten Ciamis.

1. Pengertian Intensitas

Kata intensitas berasal dari bahasa Inggris yaitu Intense yang berarti semangat, giat. Kemudian menurut Kamus Besar Bahasa Indonesia (2008: 560) intensitas diartikan sebagai keadaan tingkatan atau ukuran intensnya.

Sedangkan dalam kamus psychology adalah kuatnya tingkah laku atau pengalaman, atau sikap yang di pertahankan (Ashani M. Hafi, 1996).

Sedangkan dalam kamus besar bahasa Indonesia intensitas adalah keadaan tingkat atau ukuran intens (Departemen Pendidikan Indonesia, 2003). Intens disini merupakan sesuatu yang hebat atau sangat tinggi, bergelora atau penuh semangat sangat emosional. Menurut (Chaplin, 2006) intesitas dipahami sebagai suatu kekuatan yang mendukung suatu pendapat atau suatu sikap, (Poerwadarminta, 1989: 383) mengandung arti keadaan tingkatan atau ukuran.

2. Pengertian Ekstrakurikuler

Ekstrakurikuler adalah kegiatan pembelajaran yang sering dilakukan diluar ruang kelas dengan orientasi peningkatan peningkatan kemampuan akademis. Kegiatan yang dilakukan diluar jam pelajaran yang bertujuan untuk melatih siswa pada pengalaman-pengalaman nyata (Rohmat Mulyan, 2011: 162). Menurut Suharismi AK, kegiatan ekstrakurikuler adalah kegiatan tambahan diluar struktur program yang pada umumnya merupakan kegiatan pilihan. Sedangkan definisi kegiatan ekstrakurikuler menurut Direktorat Pendidikan Menengah Kejuruan adalah kegiatan yang dilakukan diluar jam pelajaran tatap muka, dilaksanakan di sekolah atau di luar sekolah agar lebih memperkaya dan memperluas wawasan pengetahuan dan kemampuan yang telah dipelajari dari berbagai mata pelajaran dalam kurikulum.

(B.Suryobroto, 2009: 287). Menurut An-Nahlawi (1996: 187) mengemukakan bahwa kegiatan ektra kurikuler merupakan kegiatan tambahan yang merupakan bagian dari pelajaran di sekolah dan kelulusan siswapun dipengaruhi oleh aktivitasnya dalam kegiatan ekstra kurikuler apabila kita menelurusuri dunia pendidikan Islam sejak terbitnya fajar Islam, niscaya kita akan menemukan bahwa Rasulullah senantiasa mengisi waktu senggang sahabat dengan pembinaan dan dan pendidikan tambahan.

3. Pengertian Baca Tulis Quran

Pendidikan Baca Tulis Quran dimaksudkan untuk memberikan motivasi, bimbingan, pemahaman, kemampuan dan penghayatan terhadap isi yang terkandung dalam Alquran sehingga dapat diwujudkan dalam perilaku sehari-hari sebagai manifestasi iman dan taqwa kepada Allah SWT (Dinas Pendidikan dan Kebudayaan)

Pembelajaran baca tulis Alquran bertujuan untuk memberikan kemampuan dasar kepada peserta didik dalam membaca, menulis, membiasakan dan menggemari Alquran serta menanamkan pengertian, pemahahaman, penghayatan isi kandungan ayat-ayat Alquran untuk mendorong, membina dan membimbing akhlak dan perilaku siswa agar berpedoman kepada dan sesuai dengan isi kandungan ayat Alquran. 
Disamping itu pembelajaran BTQ diarahkan untuk meningkatkan kemampuan siswa dalam hal membaca Alquran secara fasih bit tartil, memahami kandungan ayat-ayat Alquran, serta mampu menuliskannya dengan tulisan yang bagus dan benar.

4. Pengertian Prestasi Belajar

Kata prestasi belajar merupakan gabungan dari dua buah kata, "prestasi', dan 'belajar" dari dua buah kata tersebut mempunyai arti yang berbeda.

Prestasi adalah hasil dari suatu kegiatan yang telah dikerjakan, diciptakan, baik secara individual maupun kelompok (Saepul Bakhri Djamarah, 1994: 19). Sedangkan belajar adalah perubahan tingkah laku yang disebabkan oleh proses menjadi matangnya seseorang atau perubahan yang maksimal atau yang bersifat temporer (T. Raka Joni, 1997: 7).

Jadi dapat disimpulkan yang dimaksud dengan prestasi belajar adalah kecakapan nyata atau aktual ability seseorang. Di samping kecakapan manusia mempunyai kemungkinan-kemungkinan yang belum nampak, yang disebut potensial ability, karena tak seorang pun yang belajar sampai batas akhir kemampuannya. Bahkan dalam satu lapangan kependidikan tak ada seorang pun yang berkembang sepenuh-penuhnya. Tetapi ia dapat belajar lebih dari apa yang dipelajarinya. Oleh karena itu seseorang dapat meningkatkan prestasinya, di samping kemungkinan kemundurannya.

1. Pengertian Pendidikan Agama Islam

Menurut Zakiyah Darajat dalam buku Peranan Pendidikan Agama Islam (Aat Syafaat dkk, 2008: 16) bahwa Pendidikan Agama Islam adalah usaha berupa bimbingan dan usaha terhadap anak didik agar setelah selesai dari pendidikannya dapat memahami dan mengamalkan ajaran agama islam serta menjadikannya sebagai pandangan hidup (way of life).

Sedangkan menurut M. Arifin (1994: 14) Pendidikan Agama Islam yaitu proses yang mengarahkan kepada kehidupan yang lebih baik dan mengangkat derajat kemanusiaannya, sesuai dengan kemampuan dasar (fitrah) dan kemampuan ajarannya (pengaruh dari luar).

Jadi pendidikan Agama Islam, yaitu suatu usaha yang berupa pembelajaran bagi anak didik untuk dapat memahami dan mengamalkan ajaran agama yang mengarahkan kepada kehidupan yang lebih baik. Pentingnya Pendidika Agama Islam dalam pembentukan perilaku anak, serta menanamkan nilai-nilai yang terkandung di dalam agama melalui pendidikan.

2. Intensitas Kegiatan Ekstrakurikuler Baca Tulis Quran intensitas merupakan kuatnya tingkah laku atau pengalaman, atau

sikap yang di pertahankan, ataupun semangat kekuatan yang sangat hebat 
dan sangat tinggi dalam melakukan suatu aktivitas ataupun kegiatan. Kemudian ekstrakurikuler adalah tambahan yang dilaksanakan di luar jam pelajaran biasa agar memperkaya wawasan pengetahuan dan kemampuan peserta didik serta sebagai penunjang dan pendamping kegiatan intrakurikuler. Kegiatan ekstrakurikuler dapat menumbuh kembangkan potensi dan bakat yang dimiliki oleh para peserta didik.

Sedangkan Baca Tulis Quran suatu pembelajaran yang bertujuan untuk memberikan kemampuan dasar kepada peserta didik dalam membaca, menulis, membiasakan dan menggemari Alquran serta menanamkan pengertian, pemahaman, penghayatan isi kandungan ayat-ayat Alquran untuk mendorong, membina dan membimbing akhlak dan perilaku siswa agar berpedoman kepada dan sesuai dengan isi kandungan ayat Alquran.

Maka dari beberapa uraian definisi diatas dapat disimpulkan bahwa intensitas kegiatan ekstrakurikuler Baca Tulis Quran merupakan semngat yang harus dimiliki oleh setiap peserta didik dalam hal mengikuti kegiatan yang diselenggarakan diluar jam pelajaran biasa terutama dalam hal kegiatan Baca Tulis Quran yang memiliki tujuan selain menambah wawasan, juga bertujuan untuk memberikan kemampuan dasar kepada peserta didik dalam membaca, menulis, membiasakan dan menggemari Al quran.

\section{B. METODE}

Penelitian ini menggunakan metode penelitian deskriptif dengan pendekatan kuantitatif. Hal ini dimaksudkan agar penulis dapat mengetahui realita dan fakta-fakta dari sifat populasi penelitian ini secara teliti dan mendalam. Untuk mendapatkan faktafakta dari fenomena yang ada dicari data dan informasi yang faktual dari variabelvariabel. Adapun data-data yang dianalisis berbentuk angka atau bilangan setelah dilakukan proses kuantifikasi data melalui olah instrumen penelitian yang berbentuk angket yang disebarkan kepada responden.

Variabel bebas merupakan variabel yang menjadi sebab timbulnya atau berubahnya variabel terikat. Sehingga variabel independent dapat dikatakan sebagai variabel yang mempengaruhi variabel terikat. Yang menjadi variabel bebas pada penelitian ini adalah intesitas siswa dalam ekstrakurikuler Baca Tulis Quran di madrasah diniyah.

Variabel terikat adalah gejala atau unsur variabel yang dipengaruhi atau menjadi akibat, karena adanya variabel independent (bebas). Yang menjadi variabel terikat dari peneilitian ini adalah prestasi siswa dalam mata pelajaran PAI.

Populasi dalam penelitian ini adalah seluruh peserta didik di SDN 3 Cibeureum Kecamatan Sukamantri Kabupaten Ciamis pada tahun pelajaran 2017-2018 yang berjumlah 108 orang. Teknik sampling dalam penelitian ini mengunakan purposive sampling yaitu teknik sampling yang digunakan oleh peneliti jika peneliti mempunyai pertimbangan-pertimbangan tertentu di dalam pengambilan sampelnya. 
Dari jumlah populasi 108 siswa, peneliti mengambil sampel kelas VI yang berjumlah 108 siswa. Kenapa mengambil sampel hanya kelas VI saja, karena penulis menilai bahwa siswa kelas VI yang mengikuti kegiatan ekstrakurikuler begitu sangat antusias sekali dapat dilihat dari kehadirannya yang selalu tepat waktu, selalu mengikuti kegiatan yang lainnya seperti membaca, menghafal kemudian selalu bertanya terhadap sesuatu hal yang kurang dimengerti. Akan tetapi, pada kenyataannya tidak sedikit pula siswa yang selalu mendapatkan nilai rendah terutama dalam hal mata pelajaran PAI dan juga masih rendah terhadap prestasi yang didapat pada mata pelajaran PAI. Selain itu, kegiatan Baca Tulis Alquran merupakan salah satu syarat untuk siswa kelas VI supaya dapat melanjutkan kejenjang sekolah yang selanjutnya. Teknik pengumpulan data ini menggunakan angket tertutup yang sudah disediakan alternative jawabannya. Responden angket ini adalah peserta didik.

\section{Diskusi}

Dari hasil uji hipotesis diperoleh, bahwa terdapat pengaruh yang positif dan signifikan antara kegiatan ekstrakurikuler Baca Tulis Quran dengan prestasi belajar peserta didik pada mata pelajaran Pendidikan Agama Islam. Hal ini terbukti dari harga koefisien korelasi sebesar 0,88 angka tersebut jika di interprestasikan ke dalam interprestasi koefisien korelasi berada antara 0,81100,0 dengan tingkat korelasi cukup. Dan derajat determinasi hubungan sebesar

$77 \%$ dengan tingkat signifikansi 0,05 diperoleh daftar dalam daftar $t_{\text {hitung }} 4,465$. Sedangkan $t_{\text {tabel }}$ diperoleh 1,734. Maka Ha diterima dan Ho ditolak, artinya terdapat pengaruh yang signifikan antara intesitas kegiatan ekstrakurikuler dengan prestasi belajar peserta didik pada mata pelajaran Pendidikan Agama Islam.

Hasil dari deskripsi penelitian dan hasil analisis data, dapat dijabarkan sebagai berikut :

1. Pengaruh Kegiatan Ekstrakurikuler Baca Tulis Quran

Kegiatan ekstrakurikuler Baca Tulis Quran yang diselenggaran diselenggarakan di madrasah diniyah tergolong cukup baik. Hal ini berdasarkan pada hasil penelitian yang dilakukan kepada 20 responden (peserta didik) dengan menggunakan angket, kemudian dihitung skala penafsirannya dengan memperoleh hasil 49,3 yang berada pada interval 49,0 sampai 50,0 dengan klasifikasi cukup baik.

2. Prestasi Belajar Peserta Didik pada Mata Pelajaran Pendidikan Agama Islam

Prestasi belajar peserta didik pada mata pelajaran Pendidikan Agama Islam di SDN 3 Cibeureum tergolong sangat rendah. Hal ini berdasarkan pada hasil penelitian yang dilakukan kepada 20 responden (peserta didik) dengan menggunakan angket, kemudian dihitung skala penafsirannya dengan memperoleh hasil rata-rata sebesar 29,8 yang berada pada interval diantara 79,6 sampai 84,2 dengan klasifikasi sangat rendah.

3. Pengaruh Intensitas Kegiatan Ekstrakurikuler Baca Tulis Quran di Madrasah

Diniyah terhadap Prestasi Belajar Peserta Didik pada Mara Pelajaran Pendidikan Agama Islam di SDN 3 Cibeureum 
Intensitas kegiatan ekstrakurikuler BTQ di Madrasah Diniyah memberikan pengaruh yang cukup positif terhadap prestasi belajar peserta didik. Hal ini berdasarkan perhitungan korelasi antara variabel $\mathrm{X}$ dan $\mathrm{Y}$ yang menggunakan rumus rank sperman (rs) dengan harga rs sebesar 0,88. Angka korelasi rank sperman tersebut berada pada interval 0,81 sampai 100,0 dengan kualifikasi sangat tinggi. Artinya terdapat pengaruh yang sangat tinggi antara kegiatan ekstrakurikuler Baca Tulis Quran terhadap prestasi belajar peserta didik SDN 3 Cibeureum. Melalui uji hipotesis diketahui bahwa angka korelasi tersebut signifikasi, sebab terbukti $t_{\text {hitung }}$ 4,465 lebih besar dari pada $t_{\text {tabel }}$ 1,734. Dengan demikian disimpulkan bahwa hipotesis alternatif $(\mathrm{Ha})$ diterima dan hipotesis (Ho) ditolak.

\section{SIMPULAN}

Setelah melakukan pengolahan data dari hasil penelitian, dapat diambil simpulan sebagai berikut :

1. Intensitas kegiatan ekstrakurikuler Baca Tulis Quran di SDN 3 Cibeureum Kecamatan Sukamantri Kab. Ciamis cukup baik hal ini terbukti dari hasil penyebaran angket terhadap 20 responden diperoleh data dengan nilai rata-rata 49,3 yang berada pada klasifikasi cukup.

2. Prestasi belajar peserta didik pada mata pelajaran Pendidikan Agama Islam SDN 3 Cibeureum Kecamatan Sukamantri berdasarkan hasil penelitian dan pengolahan data yang diperoleh dari daftar nilai peserta didik kelas VI sebanyak 20 peserta didik menunjukan angka sangat rendah, dengan nilai rata-rata 82,3 berada pada klasifikasi sangat rendah.

3. Pengaruh intensitas kegiatan ekstrakurikuler Baca Tulis Quran di madrasah diinyah terhadap prestasi belajar pada mata pelajaran Pendidikan Agama Islam di SDN 3 Cibeureum Kecamatan Sukamantri cukup, hal ini dapat diketahui dari nilai derajat determenasi sebesar 77\%. Dengan demikian sebesar 23\% prestasi belajar peserta didik dipengaruhi oleh faktor lain, diantaranya faktor kerajinan peserta didik dalam belajar dan dukungan orang tua.

Adapun saran yang dapat disamapaikan penulis diantaranya :

Setelah diketahui persentase pengaruh kegiatan ekstrakurikuler BTQ terhadap prestasi belajar peserta didik pada mata pelajaran Pendidikan Agama Islam, maka penulis memberikan saran sebagai berikut :

a. Ketika kegiatan ekstrakurikuler memiliki kepengaruhan yang cukup terhadap prestasi bealajar, namun sayangnya masih ada yang perlu diperhatikan oleh setiap peserta didik karena masih terdapat aspek yang bisa dikatakan kurang seperti dalam hal membaca, karena masih terdapat peserta didik yang bisa dikatakan sangat kurang dalam hal membaca.

b. Kemudian untuk pendidik seharusnya lebih memberikan waktu yang cukup banyak kepada peserta didik dalam hal tanya jawab, karena dengan adanya

c. tanya jawab yang cukup peserta didik setidaknya mampu memahami hal yang kurang dipahami oleh mereka. 
d. Kurangnya dalam hal penerapan menjadikan materi yang telah didapatkan oleh peserta didik menjadi tidak maksimal. Jadi seharusnya, pendidik ataupun orang tua selalu membiasakan menerapkan setiap materi yang telah didapatkan oleh setiap peserta didik.

\section{DAFTAR PUSTAKA}

Abdurahman An-Nahlawi, (1996), Prinsip-prinsip dan Metode Pendidika Islam. Bandung: CV. Yogyakarta

Abdurahman An-Nahlawi, (1980), Prinsip-prinsip dan Metode Pendidikan Islam Dalam Keluarga Sekolah dan Masyarakat. Alih bahasa Herry Noer Ali, CV. Diponegoro, Bandung

Abuddin, Nata. 2001. Perspektif tentang Pola hubungan guru-murid. Jakarta: Raja Grafindo Persada

Al-Qur'an dan Terjemahnya

Ashani M. Hanafi, (1996), Kamus Pshycology. Surabaya: Usaha Nasional

B. Suryobroto, (2009), Proses Belajar Mengajar di Sekolah. Edisi revisi, Jakarta: Rineka Cipta

Daradjat, Zakiah, (1992), Ilmu Pendidikan Islam. Jakarta: Bumi Aksara

Daradjat, Zakiah, (1996), Ilmu Jiwa Agma. Jakarta: Bulan Bintang

Departemen Agama RI, OP. Cipt. 2006

Departemen Pendidikan dan Kebudayaan RI, (1995), Kamus Besar Bahasa

Indonesia. Cet. Jakarta: Balai Pustaka

Departemen Pendidikan Indonesia, (2003), Kamus Besar Bahasa Indonesia. Jakarta: Balai Pustaka

Dinas Pendidikan dan Kebudayaan, (2007), Kurikulum Daerah. Pasuruan http://fahrurrozi.com/kompetensi-guru-pendidikan-agama-islam/ http://Stainurulhidayah.ac.id.//Metode-Pembelajaran-Baca-Tulis-Quran.blog

Isro, M.Ag, (2013), Presentasi Kelompok I tentang Baca Tulis Alquran (BTA), Jenis, Metode dan Cara Pembelajarannya. Bumiayu.

M. Arifin, (1994), Filsafat Pendidikan Islam. Jakarta: Bumi Aksara

Muhibbin Syah, (2008), Psikologi Pendidikan Dengan Pendekatan Baru. Bandung: Remaja Rosdakarya

Partanto, dkk. Kamus Ilmiah Populer. Surabaya: Penerbit Arloka, tanpa tahun

Poerwadarminto, W.J.S, (1987), Kamus Besar Bahasa Indonesia. Jakarta: Balai Pustaka

Rohmat, Mulyana,(2011), Mengartikulasi Pendidikan Nilai. Bandung: Alfabaeta

Syafaat, dkk, (2008), Perilaku Manusia (Teori dan Pengukurannya). Cet-2, Pustaka Pelajar

Rohmat, Mulyana,(2011), Mengartikulasi Pendidikan Nilai. Bandung: Alfabaeta

Tafsir,Ahmad.1992. Ilmu Pendidikan dalam Perspektif Islam. Bandung: Remaja Rosdakarya

Tafsir, Ahmad, (1995), Ilmu Pendidikan Dalam Islam. Bandung: PT. Remaja

Rosda Karya 
TAP MPR RI NO.II/MPR/1988, Tentang Garis-garis Besar Haluan Negara. BP7 Pusat, Jakarta

Wawan,(2015), Desain Penelitian Kuantitatif. Suryalaya: Latifah Press

Wawan,(2015), Pengantar Statistik Pendidikan. Suryalaya: Latifah Press

W.S Winkell, (1987), Psikologi Pengajaran. Jakarta: Gramedia

Zainuddin, dkk, (1990), Seluk Beluk Pendidikan Al-Ghazali. Jakarta: Bumi Aksara 